\title{
Analysis of Calculation Methods Currently Practised at V4 Agricultural Holdings
}

\author{
Lenka Hudáková Stašová \\ Faculty of Economics, Technical university of Košice, Slovakia
}

\begin{abstract}
This paper assesses calculation methods in the Visegrad 4 countries (Czech Republic, Hungary, Poland and Slovakia) and, based thereon, recommends and considers activity-based costing (ABC) in the agricultural sector, while evaluating manager knowledge of $\mathrm{ABC}$ as an appropriate alternative to outdated, "conventional" methods of calculating costs that are used in practice.

It was found that a majority of agricultural holdings in the V4 are currently using conventional cost calculation methods and the most frequent reason for their failure to incorporate $\mathrm{ABC}$ is low awareness among managers.

Farms and agricultural holdings that have introduced $\mathrm{ABC}$ and utilise it to assign their costs evaluate its benefits highly positively, in particular, ABC's more accurate identification of costs, mainly overheads; more effective cost management and the accuracy of price estimates.

From this analysis and assessment, introduction of $\mathrm{ABC}$ is recommended for companies in order to obtain the different benefits associated with the method. Successfully implementing ABC leads to a number of advantages, especially in the inevitable decision-making agricultural holdings face about high overhead costs. From the information obtained, managers at agricultural holdings have little information, in most cases, about $\mathrm{ABC}$ as an appropriate alternative to the outdated "conventional" cost estimate methods practised today. It is therefore important to work on raising managers' awareness of new approaches to costing by publishing scientific articles with specific examples from practice, pointing out the advantage of the ABC method, especially with high overheads, which are almost the rule in agricultural holdings.
\end{abstract}

\section{Keywords}

Activity Based Costing method, cost calculation, agricultural holdings.

JEL: M21, M41, Q14

Hudáková Stašová, L. (2021) “Analysis of Calculation Methods Currently Practised at V4 Agricultural Holdings", AGRIS on-line Papers in Economics and Informatics, Vol. 13, No. 4, pp. 19-32. ISSN 1804-1930. DOI 10.7160/aol.2021.130403.

\section{Introduction}

Most agricultural holding managers know nothing about the significance of calculating costs. In strategic management and decision-making, only companies with advanced managements responsibly devoted to strategy and visualising further development are making such calculations. They comprise about $30 \%$ of agricultural holdings operating in Slovakia. From an economic point of view, these are considered above-average businesses. However, most farms are still using traditional cost accounting methods to address overhead.

Such economic cost management in the agricultural sector is associated with input price growth, falling production, increased competition, the macroeconomic environment and an unfavourable market situation. Agricultural costs are also influenced by natural factors such as climate, location, high in-house consumption, circulating assets and the nature of property, plant and equipment in agriculture.

Internal costs are more substantially influenced by how the holdings are managed than from external factors. But this requires managers to pay more attention to costs and emphasise cost-effectiveness in their spending. It also requires a change in attitude among managers at different agricultural holdings, still often grounded in previous practices and traditional farm management methods. They fail to pay enough attention to internal management, where such focus could ultimately lead to cost reductions. 
In today's environment, it is critical to seek out ways to optimise costs and identify problem areas, where an activity-based cost management model can be applied to ensure long-term competiveness. Activity-based management (ABM) includes activity-based costing (ABC), activity-based planning (ABP), activity-based budgeting $(\mathrm{ABB})$ and activity-based accounting (ABA). These are so-called "AB" techniques.

In the 1980's much criticisms were raised regarding the ability of traditional cost accounting to provide relevant, timely, and accurate information to the management. During that period, $\mathrm{ABC}$ has emerged as one of the management accounting tools that recognizes such concern. Since then $\mathrm{ABC}$ has gained its popularity and has received substantial attention from various parties including the academicians, practitioners, and industries. ABC has also been studied from various perspectives for quite some time in many countries. Literatures are enriched with studies that have argued that the adoption of $\mathrm{ABC}$ benefits organizations. Unfortunately, studies have also found that the level of $\mathrm{ABC}$ adoption is still considered low. Many organizations still use the traditional cost accounting methods in dealing with overhead costs. (Maelah and Ibrahim, 2007). The implementation of $\mathrm{ABC}$ could improve firms both financial performance and nonfinancial performance (Fei and Isa, 2011).

Large scale agricultural enterprises that depend heavily on capital investments require rational allocation of the available resources and efficient utilization of the existing production technology. The accurate and reliable computation of cost per unit of product is crucial for the evaluation of the economic performance of the enterprises and the investigation of the optimal allocation of the production factors in different activities. The concept of Activity Based Costing methodology, which is of great importance in the system of cost accounting, allows the allocation of indirect costs to specific activities and individual products, overcoming the drawbacks of the traditional method of cost accounting (Koutouzidou et al., 2015).

In order to solve problems with the allocation of indirect costs, it is appropriate to use the approach it supports a structured decision making process $-\mathrm{ABC}$ approach. $\mathrm{ABC}$ is a methodology developed to face the increasing level of fixed costs in the modern companies (Cooper and Kaplan, 1988), (Johnson and Kaplan, 1987). Allocation of fixed costs to products is complex and $\mathrm{ABC}$ "measures costs and performances of activities, resources and cost objects, assigns resources to activities and activities to cost objects based on their use, and recognizes causal relationships of cost drivers to activities" (Dierks and Cokins, 2000).

Given the highly competitive environment in which the Agribusiness is inserted, there is a growing need for professional management of rural properties, which requires the use of methods that assist decision making. In this context, it is noticed that cost management is an essential tool for the administration of rural enterprises. (Sampaio et al., 2011).

Because of the ongoing income pressure in agriculture, the analysis of services and costs at farm activity level is gaining in importance. The advantage of the ABC approach would be to achieve a wider impact. This would encourage cost awareness on farms, which could ultimately improve income. (Gazzarin and Lips, 2018). The agricultural companies need to deepen the effective use of the appropriate techniques for the strategic management of costs of the processes and activities to meet the different demands of the agribusiness economic system, which is situated in an environment of new perspectives and challenges arising from the reshaping of markets and the continuous improvement of competitiveness. (da Silva et al., 2019) Facing increasingly competitive market demands, agricultural producers must act as managers of their property, knowing the strengths and bottlenecks in production systems. In this perspective, there is a methodology activity-based costing system (ABC), a cost management tool, used when there is a mix of products, to determine the unit costs of production (Araújo et al., 2019).

The method Activity Based Costing is an instrument to better assignment of costs to activities. The method is appropriate for manufacturing corporations, distribution centres, agriculture, but also for the field of services, especially in the hospitality. The method has advantages and benefits for whole range of companies without difference to branch classification. (Dejnega, 2011), (Dalci et al., 2010). ABC has capability to calculate the overhead cost more precisely and generate the information that contributes to improving the overall production activity (Gholami et al., 2019).

ABC demonstrates how significant cost-saving opportunities can be identified in the business and offers a first step in a change in cost management thinking (Schulze et al, 2012). The ABC cost model could be the most 
appropriate tool to manage resources and provide the information needed to achieve the strategic objectives set out by the institution (enterprise), since it would allow to know at all times what is done and how it is done, since the implementation of the it implies the definition of the main activities developed in the institution, how they are being carried out and the cost of their realization. Information would be available on the effectiveness and efficiency of the activities (Del-Río Sánchez et al., 2019). ABC model is a model of cost management system has been developed that takes into account certain directions of information flows between the elements of the organizational structure of cost management at all stages, making possible the effective impact on the use of resources (Perevozova et al., 2019). Accounting approach known as ABC model allows for decisions toward a company's sustainability by acting on both the amount and kind of a company's product that should be managed, as well as on the effective increase of a specific company's activity or process (Neto et al., 2018).

An $\mathrm{ABC}$ system is based on the idea that products make use of certain general activities developed inside the company and these activities require some resources to be done. It means that, first, the cost of the resources are allocated to the activities and, then, the costs of activities are allocated to the products (costs objects) using specific activity drivers for each activity. In this way, it is possible to assign overheads to products in a more accurate and precise way. This logic enables managers to have a deeper control on how products or services, brands, customers, channels of distribution, or facilities consume resources and generate costs. Furthermore, this logic fosters the understanding of patterns of resource consumption at the micro level. Managers can have access to a deeper level of information that enables corrective actions directed to the enhancement of revenues, profitability and cost reduction. ABC prevents some distortions related to product cost information that arise from traditional accounting systems where the overheads (indirect costs) are arbitrarily attributed, usually in proportion to an activity's direct cost. Traditional systems create higher distortions when there are sophisticated production structures, with a wide range of products or services that require the assignment of large amount of general costs (Carli and Canavari, 2013).

Arora and Raju (2018) found in their study a number of employees and the percentage of overheads as significant company characteristic factors for the implementation of the $\mathrm{ABC}$ system. More adequate pricing decisions, better overhead cost allocation, and more accurate product cost were found as the motives for the implementation of the ABC system. The major challenges faced during the adoption process of the $\mathrm{ABC}$ system are selecting cost drivers, high cost of $\mathrm{ABC}$, data collection difficulties, and uncertainty of $\mathrm{ABC}$ benefits. Costly to switch to $\mathrm{ABC}$, easy to track cost, satisfied with current system, and uncertainty of $A B C$ benefits were found as the main causes for non-adoption of $\mathrm{ABC}$. The study recommended the implementation of the $\mathrm{ABC}$ system to get the various benefits associated with it.

Elhamma (2015) found in his study that the management accounting system based on $\mathrm{ABC}$ method results in a better performance for enterprises that have adopted it. Finally, they demonstrated that the firms operating in an uncertain and dynamic environment have an interest to adopt this new method of the management accounting, but the firms operating in a certain and stable environment are indifferent between adopting and not adopting this method.

The activity-based costing (ABC) systems emerged as a management accounting innovation in the mid-1980's in response to dissatisfaction with traditional management accounting techniques and heightened international competition. Although $\mathrm{ABC}$ provides many advantages for managerial decision making, $\mathrm{ABC}$ tends to be outdated due to its limitations and is substituted by the time-driven activity-based costing (TDABC) systems. TDABC requires estimates of only two parameters: how much it costs per time unit of capacity to supply resources to activities and how much time it takes to perform each activity. TDABC allows incorporation of variation in the time demands made by different types of processes and consequently the representation of all possible combinations of activities that a process performs (Park et al., 2019).

Allain and Laurin (2018) argue that managers should be aware that designing and implementing a cost system that can simultaneously be used in both controlling and enabling ways is a very difficult, if not an insurmountable challenge.

Activity-based costing (ABC) looks like a great way to manage a company's limited resources. But executives who have tried to implement ABC in their organizations on any significant scale have often abandoned the attempt in the face of rising costs and employee irritation. They should try again, because a new approach 
sidesteps the difficulties associated with largescale $\mathrm{ABC}$ implementation, write Kaplan, and Anderson (2004) about an innovated ABC method - about the Time-driven activity-based costing. In the revised model, managers estimate the resource demands imposed by each transaction, product, or customer, rather than relying on timeconsuming and costly employee surveys. This method is simpler since it requires, for each group of resources, estimates of only two parameters: how much it costs per time unit to supply resources to the business's activities (the total overhead expenditure of a department divided by the total number of minutes of employee time available) and how much time it takes to carry out one unit of each kind of activity (as estimated or observed by the manager). This approach also overcomes a serious technical problem associated with employee surveys: the fact that, when asked to estimate time spent on activities, employees invariably report percentages that add up to 100 . Under the new system, managers take into account time that is idle or unused. Armed with the data, managers then construct time equations, a new feature that enables the model to reflect the complexity of real-world operati and activity characteristics cause processing times to vary. This Tool Kit uses concrete examples to demonstrate how managers can obtain meaningful cost and profitability information, quickly and inexpensively. Rather than endlessly updating and maintaining $\mathrm{ABC}$ data, they can now spend their time addressing the deficiencies the model reveals: inefficient processes, unprofitable products and customers, and excess capacity.

\section{Materials and methods}

Based on the above ascertained facts, the aim of the paper is to evaluate the calculation methods used by agricultural holdings in the Visegrad 4 countries (Czech Republic, Hungary, Poland and Slovakia) and therefrom recommend and consider activity-based costing in the agricultural sector, while evaluating knowledge managers have of $\mathrm{ABC}$ as an appropriate alternative to outdated, "conventional" methods of calculating costs that are used in practice.

In order to reach this objective, the following research questions and hypotheses were set:

\section{Research questions:}

What other calculation methods are agricultural holdings in the Visegrad 4 countries (Czech Republic, Hungary, Poland and Slovakia) presently using?
What percentage of agricultural holdings knows $\mathrm{ABC}$ and what percentage of them in each V4 country is actually utilising it compared to the others?

What are the advantages and weaknesses of practising $\mathrm{ABC}$ among agricultural holdings in the V4 (why has it not been successful in some farms and why are other farms refusing to introduce it)?

\section{Hypotheses:}

Hypothesis 1: Most agricultural holdings in the V4 are currently using "conventional" methods to calculate costs.

Hypothesis 2: The most common reason for agricultural holdings in the V4 not using ABC is low awareness of the method among managers.

Hypothesis 3: There are differences among the countries in the various types of calculation methods used.

Hypothesis 4: ABC's assessment as time consuming varies depending on the country where the agricultural holding is located.

Hypothesis 5: Management's doubts about ABC's benefits vary depending on the country where the agricultural holding is located.

The hypotheses were verified using the significance test for a proportion, the Wilcoxon signedrank test, the Chi-square test of independence, and the Kruskal-Wallis one-way analysis of variance.

Questionnaires were used to capture data, with replies received from a total 98 agricultural holdings. The questionnaire was sent out and the data collected in the period January-April 2020. All subjects in the analyzed set of companies are trading companies - limited liabilty company, joint stock company, cooperative. Entities of natural persons are not included in the file. Likewise, all agricultural entities in the analyzed group perform mixed crops and livestock production (classification of production focus according to FADN). In terms of the size of enterprises, the file includes almost all economic size classes according to FADN (II.-XIII.), which for the purposes of research in the article are divided into sizes according to two criteria - according to the number of employees and according to the area of agricultural land in ha.

The number of holdings in the four countries and their size are shown in Tables 1 and Table 2. 


\begin{tabular}{|l|c|c|c|c|c|c|c|c|c|c|}
\hline \multirow{2}{*}{$\begin{array}{l}\text { Company size } \\
\text { by number of employees }\end{array}$} & \multicolumn{2}{|c|}{ CZ } & \multicolumn{2}{c|}{ HU } & \multicolumn{2}{c|}{ PL } & \multicolumn{2}{c|}{ SK } & \multicolumn{2}{c|}{ Together } \\
\cline { 2 - 11 } & $\mathbf{N}$ & $\mathbf{\%}$ & $\mathbf{N}$ & $\mathbf{\%}$ & $\mathbf{N}$ & $\mathbf{\%}$ & $\mathbf{N}$ & $\mathbf{\%}$ & $\mathbf{N}$ & $\%$ \\
\hline $\begin{array}{l}\text { Microenterprise } \\
\text { (up to 10 employees) }\end{array}$ & 9 & $37.5 \%$ & 6 & $28.6 \%$ & 7 & $30.4 \%$ & 6 & $20.0 \%$ & 28 & $28.6 \%$ \\
\hline $\begin{array}{l}\text { Small company } \\
\text { (11 - 50 employees) }\end{array}$ & 8 & $33.3 \%$ & 10 & $47.6 \%$ & 10 & $43.5 \%$ & 12 & $40.0 \%$ & 40 & $40.8 \%$ \\
\hline $\begin{array}{l}\text { Medium company } \\
\text { (51 - 250 employees) }\end{array}$ & 6 & $25.0 \%$ & 5 & $23.8 \%$ & 5 & $21.7 \%$ & 11 & $36.7 \%$ & 27 & $27.6 \%$ \\
\hline $\begin{array}{l}\text { Big company } \\
\text { (over 250 employees) }\end{array}$ & 1 & $4.2 \%$ & 0 & $0.0 \%$ & 1 & $4.3 \%$ & 1 & $3.3 \%$ & 3 & $3.1 \%$ \\
\hline Together & 24 & 100.0 & 21 & 100.0 & 23 & 100.0 & 30 & 100.0 & 98 & 100.0 \\
\hline
\end{tabular}

Source: own processing

Table 1: Numbers of holdings and their size by number of employees in V4 countries.

\begin{tabular}{|l|c|c|c|c|c|c|c|c|c|c|}
\hline \multirow{2}{*}{$\begin{array}{l}\text { Company size by area } \\
\text { of land }\end{array}$} & \multicolumn{2}{|c|}{ CZ } & \multicolumn{2}{c|}{ HU } & \multicolumn{2}{c|}{ PL } & \multicolumn{2}{c|}{ SK } & \multicolumn{2}{c|}{ Together } \\
\cline { 2 - 12 } & $\mathbf{N}$ & $\mathbf{\%}$ & $\mathbf{N}$ & $\mathbf{\%}$ & $\mathbf{N}$ & $\mathbf{\%}$ & $\mathbf{N}$ & $\mathbf{\%}$ & $\mathbf{N}$ & $\%$ \\
\hline Less than 500 ha & 8 & $33.3 \%$ & 6 & $28.6 \%$ & 7 & $30.4 \%$ & 10 & $33.3 \%$ & 31 & $31.6 \%$ \\
\hline $501-1000$ ha & 6 & $25.0 \%$ & 6 & $28.6 \%$ & 5 & $21.7 \%$ & 7 & $23.3 \%$ & 24 & $24.5 \%$ \\
\hline $10001-1500$ ha & 5 & $20.8 \%$ & 6 & $28.6 \%$ & 7 & $30.4 \%$ & 7 & $23.3 \%$ & 25 & $25.5 \%$ \\
\hline $1501-2000$ ha & 2 & $8.3 \%$ & 2 & $9.5 \%$ & 1 & $4.3 \%$ & 4 & $13.3 \%$ & 9 & $9.2 \%$ \\
\hline More than 2,000 ha & 3 & $12.5 \%$ & 1 & $4.8 \%$ & 3 & $13.0 \%$ & 2 & $6.7 \%$ & 9 & $9.2 \%$ \\
\hline Together & 24 & 100.0 & 21 & 100.0 & 23 & 100.0 & 30 & 100.0 & 98 & 100.0 \\
\hline
\end{tabular}

Source: own processing

Table 2: Numbers of holdings and their size by area of agricultural land in V4 countries.

The questionnaire contained the items below:

1. Size of the holding, according to the number of people employed there and its measured land area.

2. Other calculation methods currently used to estimate the holding's costs.

3. Thoughts about changing the methods presently utilised and what new method was being contemplated.

4. Awareness of activity-based costing.

5. How long activity-based costing had been used and if the holding was using it.

6. What benefits activity-based costing had bought the holding.

7. Whether activity-based costing had met expectations.

8. Why the holding was not using activitybased costing.

9. If the holding had tried activity-based costing and was no longer using it, why it had not been successful there.

The results for questions 6-9 are rated on a scale: 4 - definitely yes, 3 - rather yes, 2 - rather no, 1 - definitely no, 0 - I don't know, I can't express myself.

\section{Results and discussion}

\section{Analysing the calculation methods used}

Table 3 shows the methods the holdings used to estimate agricultural costs, by country. The most popular calculation method currently practised by them is mark-up, considered to be the conventional method. It is used by most holdings in all 4 countries. According to our findings, only 6\% of holdings are considering a change in the currently used calculation method. Just over $30 \%$ currently use the ABC method.

Table 4 describes overall ABC awareness among agricultural holdings. It was mentioned the most among all the holdings which were contacted and had replied to the questionnaires (by more than $31 \%$ ) that they knew about the method, but had elected not to utilise it. What is striking is that $28 \%$ of the farms surveyed had not even known about ABC.

Table 5 shows how long the agricultural holdings had used ABC to estimate costs. The question was only answered by those practising it at the time when they replied to the questionnaire. Table 6 summarises the farms whose expectations were met after they had implemented ABC. 


\begin{tabular}{|l|c|c|c|c|c|c|c|c|c|c|}
\hline \multirow{2}{*}{$\begin{array}{l}\text { Calculation methods } \\
\text { used }\end{array}$} & \multicolumn{2}{|c|}{ CZ } & \multicolumn{2}{c|}{ HU } & \multicolumn{2}{c|}{ PL } & \multicolumn{2}{c|}{ SK } & \multicolumn{2}{c|}{ Together } \\
\cline { 2 - 12 } & $\mathbf{N}$ & $\mathbf{\%}$ & $\mathbf{N}$ & $\mathbf{\%}$ & $\mathbf{N}$ & $\mathbf{\%}$ & $\mathbf{N}$ & $\mathbf{\%}$ & $\mathbf{N}$ & $\%$ \\
\hline Mark-up calculation & 12 & $50.0 \%$ & 11 & $52.4 \%$ & 15 & $65.2 \%$ & 13 & $43.3 \%$ & 51 & $52.0 \%$ \\
\hline $\begin{array}{l}\text { Calculation of combined } \\
\text { outputs }\end{array}$ & 3 & $12.5 \%$ & 0 & $0.0 \%$ & 0 & $0.0 \%$ & 5 & $16.7 \%$ & 8 & $8.2 \%$ \\
\hline $\begin{array}{l}\text { Calculation of variable } \\
\text { costs }\end{array}$ & 0 & $0.0 \%$ & 2 & $9.5 \%$ & 0 & $0.0 \%$ & 1 & $3.3 \%$ & 3 & $3.1 \%$ \\
\hline $\begin{array}{l}\text { Process calculation } \\
\text { (ABC) }\end{array}$ & 9 & $37.5 \%$ & 8 & $38.1 \%$ & 8 & $34.8 \%$ & 11 & $36.7 \%$ & 36 & $36.7 \%$ \\
\hline Together & 24 & 100.0 & 21 & 100.0 & 23 & 100.0 & 30 & 100.0 & 98 & 100.0 \\
\hline
\end{tabular}

\begin{tabular}{|l|c|c|c|c|c|c|c|c|c|c|}
\hline \multirow{2}{*}{ Thinking about change } & \multicolumn{2}{|c|}{ CZ } & \multicolumn{2}{c|}{ HU } & \multicolumn{2}{c|}{ PL } & \multicolumn{3}{c|}{ SK } & \multicolumn{2}{c|}{ Together } \\
\cline { 2 - 12 } & $\mathbf{N}$ & $\mathbf{\%}$ & $\mathbf{N}$ & $\mathbf{\%}$ & $\mathbf{N}$ & $\mathbf{\%}$ & $\mathbf{N}$ & $\mathbf{\%}$ & $\mathbf{N}$ & $\mathbf{\%}$ \\
\hline Yes & 1 & $4.2 \%$ & 2 & $9.5 \%$ & 1 & $4.3 \%$ & 2 & $6.7 \%$ & 6 & $6.1 \%$ \\
\hline No & 23 & $95.8 \%$ & 19 & $90.5 \%$ & 22 & $95.7 \%$ & 28 & $93.3 \%$ & 92 & $93.9 \%$ \\
\hline Together & 24 & 100.0 & 21 & 100.0 & 23 & 100.0 & 30 & 100.0 & 98 & 100.0 \\
\hline
\end{tabular}

Source: own processing

Table 3: Use of calculation methods in agricultural holdings.

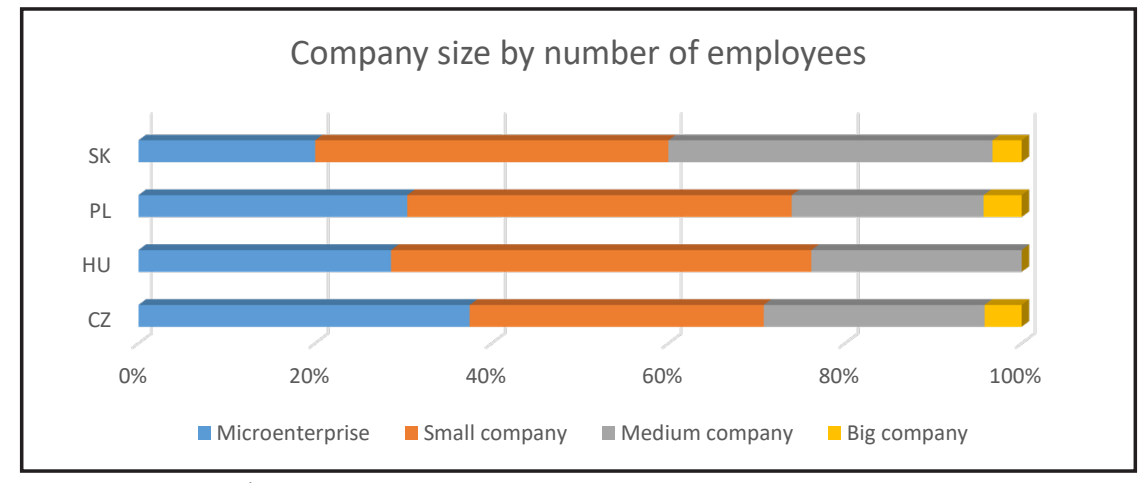

Source: own research

Figure 1: Use of calculation methods in agricultural holdings.

\begin{tabular}{|l|c|c|c|c|c|c|c|c|c|c|}
\hline \multirow{2}{*}{$\begin{array}{l}\text { Attitudes to the ABC } \\
\text { method }\end{array}$} & \multicolumn{2}{|c|}{$\mathbf{C Z}$} & \multicolumn{2}{c|}{ HU } & \multicolumn{2}{c|}{ PL } & \multicolumn{2}{c|}{ SK } & \multicolumn{2}{c|}{ Together } \\
\cline { 2 - 11 } & $\mathbf{N}$ & $\mathbf{\%}$ & $\mathbf{N}$ & $\mathbf{\%}$ & $\mathbf{N}$ & $\mathbf{\%}$ & $\mathbf{N}$ & $\mathbf{\%}$ & $\mathbf{N}$ & $\mathbf{\%}$ \\
\hline $\begin{array}{l}\text { We did not meet, we do } \\
\text { not know }\end{array}$ & 6 & $25.0 \%$ & 6 & $28.6 \%$ & 6 & $26.1 \%$ & 10 & $33.3 \%$ & 28 & $28.6 \%$ \\
\hline We know, we don't use it & 7 & $29.2 \%$ & 7 & $33.3 \%$ & 9 & $39.1 \%$ & 8 & $26.7 \%$ & 31 & $31.6 \%$ \\
\hline We are introducing ABC & 5 & $20.8 \%$ & 4 & $19.0 \%$ & 2 & $8.7 \%$ & 4 & $13.3 \%$ & 15 & $15.3 \%$ \\
\hline We use & 4 & $16.7 \%$ & 4 & $19.0 \%$ & 6 & $26.1 \%$ & 7 & $23.3 \%$ & 21 & $21.4 \%$ \\
\hline We tried, unsuccessfully & 2 & $8.3 \%$ & 0 & $0.0 \%$ & 0 & $0.0 \%$ & 1 & $3.3 \%$ & 3 & $3.1 \%$ \\
\hline Together & 24 & 100.0 & 21 & 100.0 & 23 & 100.0 & 30 & 100.0 & 98 & 100.0 \\
\hline
\end{tabular}

Source: own processing

Table 4: Attitudes towards the Activity Based Costing method by country.

\begin{tabular}{|l|c|c|c|c|c|c|c|c|c|c|}
\hline \multirow{2}{*}{$\begin{array}{l}\text { Length of use of the } \\
\text { ABC }\end{array}$} & \multicolumn{2}{|c|}{ CZ } & \multicolumn{2}{c|}{ HU } & \multicolumn{2}{c|}{ PL } & \multicolumn{3}{c|}{ SK } & \multicolumn{2}{c|}{ Together } \\
\cline { 2 - 13 } & mean & $\mathbf{1 0 2 . 0 0}$ & $\mathbf{7 8 . 0 0}$ & $\mathbf{7 8 . 0 0}$ & $\mathbf{9 2 . 5 7}$ & $\mathbf{8 7 . 4 3}$ & $\mathbf{N}$ & $\mathbf{\%}$ & $\mathbf{N}$ & $\mathbf{\%}$ \\
\hline standard deviation & 12.00 & 20.78 & 43.43 & 39.63 & 33.54 & $4.3 \%$ & 2 & $6.7 \%$ & 6 & $6.1 \%$ \\
\hline $\mathrm{N}$ & 4 & 4 & 6 & 7 & 21 & $95.7 \%$ & 28 & $93.3 \%$ & 92 & $93.9 \%$ \\
\hline Together & 24 & 100.0 & 21 & 100.0 & 23 & 100.0 & 30 & 100.0 & 98 & 100.0 \\
\hline
\end{tabular}

Source: own processing

Table 5: Length of use of the $\mathrm{ABC}$ method in months. 


\begin{tabular}{|l|c|c|c|c|c|c|c|c|c|c|}
\hline \multirow{2}{*}{ Meeting the expectations } & \multicolumn{2}{|c|}{ CZ } & \multicolumn{2}{c|}{ HU } & \multicolumn{2}{c|}{ PL } & \multicolumn{3}{c|}{ SK } & \multicolumn{2}{c|}{ Together } \\
\cline { 2 - 13 } & mean & $\mathbf{3 . 5 0}$ & $\mathbf{3 . 2 5}$ & $\mathbf{3 . 1 7}$ & $\mathbf{3 . 4 3}$ & $\mathbf{3 . 3 3}$ & $\mathbf{N}$ & $\mathbf{\%}$ & $\mathbf{N}$ & \% \\
\hline standard deviation & 0.58 & 0.96 & 0.41 & 0.53 & 0.58 & $4.3 \%$ & 2 & $6.7 \%$ & 6 & $6.1 \%$ \\
\hline $\mathrm{N}$ & 4 & 4 & 6 & 7 & 21 & $95.7 \%$ & 28 & $93.3 \%$ & 92 & $93.9 \%$ \\
\hline Together & 24 & 100.0 & 21 & 100.0 & 23 & 100.0 & 30 & 100.0 & 98 & 100.0 \\
\hline
\end{tabular}

Source: own processing

Table 6: Meeting the expectations of using the ABC method.

The respondents that had already introduced $\mathrm{ABC}$ into their estimation of costs were asked to evaluate the benefits on a four-point scale. Twenty-one agricultural holdings responded to the question. Possible reasons were arranged in descending order by the average of the scores (Table 7).

As is evident in Table 7, respondents appreciated the more accurate identification of costs, especially of overheads. Here the mean score of 3.95 was virtually the maximum value possible, reached in all countries except for the Czech Republic, where the average was only 3.75 .

The managers also highly appreciated the accuracy of the calculated price estimates. In the Czech Republic and Slovakia, the scores averaged the maximum 4.00, while in Poland it was 3.50 and in Hungary 3.00. Across all countries, the mean was 3.67 .

More effective cost management was rated as an advantage of $\mathrm{ABC}$, receiving the third highest mean score of 3.57, with recognition of the fair value of activities and true costs particularly cited as a reason. This factor was particularly appreciated extremely highly by respondents in Slovakia (4.00), while it was still significant in the other countries: 3.50 in the Czech Republic, 3.33 in Poland and 3.25 in Hungary.

Ranked fourth among the benefits, from their replies to the questionnaires, was $A B C$ 's ability to clarify the economic efficiency of activities. The mean score of 3.48 is just slightly lower than the next highest benefit rated. Managers in the Czech Republic mainly cited this factor. The variance of replies from respondents in other countries was greater, but overall they still gave a positive opinion (Poland: 3.50, Slovakia: 3.29 and Hungary 3.25).

As with the previous factor, the respondents also evaluated the quality and effectiveness of monthly final calculations, scoring an average of 3.48 across all countries. Czech respondents again unanimously rated this factor with the highest possible score of 4.00, while agricultural holdings responding in Hungary (3.50), Poland (3.33) and Slovakia (3.25) gave positive evaluations, but the variance between opinions was greater.

When evaluating the cost analysis of activities, respondents within the countries rarely agreed. While all holdings in the Czech Republic and Hungary evaluated it with the maximum possible score of 4.00, all of the respondents in Poland and Slovakia scored it only slightly positive (3.00), and so the mean across all four countries was only 3.38 .

Monthly customer and product evaluations were rated even lower as a benefit among the agricultural holdings responding to the questionnaire, with scores averaging 3.29. All of the respondents in the Czech Republic again rated them the maximum 4.00, while respondents in Poland (3.50) and Slovakia (3.00) appreciated them less and the 2.75 average among Hungarian holdings was the lowest score.

Respondents were even more sceptical about the remaining two possible benefits. The possibility $\mathrm{ABC}$ provides of performancebased compensation according to real economic benefits only scored an average of 2.86 , where responding agricultural holdings in the Czech Republic again rated it the highest (3.50), followed by Slovakia (3.00), Hungary (2.75) and the lowest by Poland (2.33).

Respondents considered product and customer portfolio optimisation to be the least significant advantage of ABC. The overall mean here was 2.62 , where it was rated highest by farms in the Czech Republic (3.50) and lowest in Hungary (2.75). The perception of portfolio optimisation found in Poland (mean of 2.33) and Slovakia (2.29) was practically indecisive because of the variance in responses.

Agricultural holdings responding that they did not use $\mathrm{ABC}$ were also asked to provide reasons for their decision. Table 8 shows their answers, broken down by country. Again the reasons are arranged in descending order.

All of them agreed that they were not aware of the method, which was reflected in all of the V4 


\begin{tabular}{|c|c|c|c|c|c|c|}
\hline \multirow{2}{*}{ Benefits of implementing $\mathrm{ABC}$} & & $\mathbf{C Z}$ & HU & PL & SK & Together \\
\hline & Number & 4 & 4 & 6 & 7 & 21 \\
\hline \multirow{2}{*}{$\begin{array}{l}\text { More accurate identification of costs, especially } \\
\text { of overheads }\end{array}$} & mean & 3.75 & 4 & 4 & 4 & 3.95 \\
\hline & stand. deviation & 0.5 & 0 & 0 & 0 & 0.22 \\
\hline \multirow{2}{*}{ Accuracy of the calculated price estimates } & mean & 4 & 3 & 3.5 & 4 & 3.67 \\
\hline & stand. deviation & 0 & 0 & 0.55 & 0 & 0.48 \\
\hline \multirow{2}{*}{$\begin{array}{l}\text { More effective cost management (fair valuation } \\
\text { of activities and cost objects) }\end{array}$} & mean & 3.5 & 3.25 & 3.33 & 4 & 3.57 \\
\hline & stand. deviation & 0.58 & 0.5 & 0.52 & 0 & 0.51 \\
\hline \multirow{2}{*}{$\begin{array}{l}\text { Transparency of economic efficiency of activities, } \\
\text { targeted distribution of overheads for specific } \\
\text { business activities }\end{array}$} & mean & 4 & 3.25 & 3.5 & 3.29 & 3.48 \\
\hline & stand. deviation & 0 & 0.5 & 0.55 & 0.49 & 0.51 \\
\hline \multirow{2}{*}{$\begin{array}{l}\text { Process calculations - better monthly final } \\
\text { calculations of products and evaluation of their } \\
\text { efficiency }\end{array}$} & mean & 4 & 3.5 & 3.33 & 3.29 & 3.48 \\
\hline & tand. deviation & 0 & 0.58 & 0.52 & 0.49 & 0.51 \\
\hline \multirow{2}{*}{ Cost analysis of activities } & mean & 4 & 4 & 3 & 3 & 3.38 \\
\hline & stand. deviation & 0 & 0 & 0 & 0 & 0.5 \\
\hline \multirow{2}{*}{$\begin{array}{l}\text { Monthly evaluation of profit and economic value } \\
\text { added by customers and products }\end{array}$} & mean & 4 & 2.75 & 3.5 & 3 & 3.29 \\
\hline & stand. deviation & 0 & 0.5 & 0.55 & 0 & 0.56 \\
\hline \multirow{2}{*}{$\begin{array}{l}\text { Performance-based compensation according to real } \\
\text { economic benefit }\end{array}$} & mean & 3.5 & 2.75 & 2.33 & 3 & 2.86 \\
\hline & stand. deviation & 0.58 & 0.5 & 0.52 & 0 & 0.57 \\
\hline \multirow{2}{*}{ Product and customer portfolio optimisation } & mean & 3.5 & 2.75 & 2.33 & 2.29 & 2.62 \\
\hline & tand. deviation & 0.58 & 0.5 & 0.52 & 0.49 & 0.67 \\
\hline
\end{tabular}

Source: own processing

Table 7: Benefits of implementing ABC.

\begin{tabular}{|c|c|c|c|c|c|c|}
\hline \multirow{2}{*}{ Reasons for not using $\mathrm{ABC}$} & & $\mathbf{C Z}$ & HU & $\mathbf{P L}$ & SK & Together \\
\hline & Number & 6 & 6 & 9 & 10 & 31 \\
\hline \multirow{2}{*}{ Not aware of the method ABC } & mean & 4.00 & 4.00 & 4.00 & 4.00 & 4.00 \\
\hline & stand. deviation & 0.00 & 0.00 & 0.00 & 0.00 & 0.00 \\
\hline \multirow{2}{*}{ Management's doubts about ABC's benefits } & mean & 3.00 & 4.00 & 4.00 & 3.88 & 3.74 \\
\hline & stand. deviation & 0.00 & 0.00 & 0.00 & 0.35 & 0.44 \\
\hline \multirow{2}{*}{$\begin{array}{l}\text { Assumption that implementation would be time- } \\
\text { consuming }\end{array}$} & mean & 3.00 & 4.00 & 3.78 & 4.00 & 3.71 \\
\hline & stand. deviation & 0.00 & 0.00 & 0.44 & 0.00 & 0.46 \\
\hline \multirow{2}{*}{$\mathrm{ABC}$ is unsuitable for their agricultural holdings } & mean & 3.29 & 4.00 & 3.56 & 3.50 & 3.58 \\
\hline & stand. deviation & 0.49 & 0.00 & 0.53 & 0.53 & 0.50 \\
\hline \multirow{2}{*}{ Resistance to change from staff employed } & mean & 2.43 & 1.86 & 2.56 & 2.63 & 2.39 \\
\hline & stand. deviation & 0.98 & 1.07 & 1.13 & 0.52 & 0.95 \\
\hline
\end{tabular}

Source: own processing

Table 8: Reasons for not using ABC.

countries equally with the maximum score of 4.00 .

Respondents likewise agreed more or less on management's doubts about ABC's benefits for the agricultural holding, with a mean score of 3.74 among them. All of the respondents in Hungary and Poland fully agreed (4.00), while most in Slovakia (3.88) and the Czech Republic (3.00) somewhat agreed.

Another common determinant for using $\mathrm{ABC}$ is the assumption that implementation would be time-consuming (mean score of 3.71 across all countries). All of the respondents in Hungary and Slovakia were especially convinced (4.00), while respondents in Poland (3.78) and the Czech Republic (3.00) were less convinced.

Even though the respondents admitted their ignorance of $\mathrm{ABC}$, they also evaluated it as unsuitable for their agricultural holdings. The mean score of 3.58 indicates a high level of agreement among them. All of the respondents from Hungary agreed with the statement (4.00), while there was slight overall agreement expressed 
by respondents from Poland (3.56), Slovakia (3.50) and the Czech Republic (3.29).

Resistance to change from staff employed at the agricultural holdings was not considered a significant reason for the failure to introduce ABC. The mean score of 2.39 generally indicates a neutral opinion. Respondents in Slovakia (2.63), Poland (2.56) and the Czech Republic (2.43) share this view a bit more than respondents in Hungary, whose responding agricultural holdings in general rather disagreed with this reason for not implementing $\mathrm{ABC}$ (1.86).

Respondents from agricultural holdings whose implementation of $\mathrm{ABC}$ had been unsuccessful were asked about the reasons for the lack of success. As only three farms had mentioned it, their responses were not broken down by country - see Table 9.

\begin{tabular}{|l|l|c|}
\hline Reasons for failure & Number & $\mathbf{3}$ \\
\hline \multirow{2}{*}{$\begin{array}{l}\text { Difficulty of project } \\
\text { implementing }\end{array}$} & mean & $\mathbf{4 . 0 0}$ \\
\cline { 2 - 3 } & stand. deviation & 0.00 \\
\hline \multirow{2}{*}{$\begin{array}{l}\text { Long time required for } \\
\text { implementation }\end{array}$} & mean & $\mathbf{3 . 3 3}$ \\
\cline { 2 - 3 } & stand. deviation & 0.58 \\
\hline \multirow{2}{*}{$\begin{array}{l}\text { Management doubts about } \\
\text { project benefits }\end{array}$} & mean & $\mathbf{3 . 0 0}$ \\
\cline { 2 - 3 } & stand. deviation & 0.00 \\
\hline $\begin{array}{l}\text { No cooperation from } \\
\text { interested staff }\end{array}$ & mean & $\mathbf{2 . 3 3}$ \\
\cline { 2 - 3 } & stand. deviation & 0.58 \\
\hline Problems setting up a change & mean & $\mathbf{2 . 3 3}$ \\
\cline { 2 - 3 } in cost tracking & stand. deviation & 0.58 \\
\hline
\end{tabular}

Source: own processing

Table 9: Reasons for failure of the ABC.

The findings indicated the most common reason for failure, where all three agreed, was the challenge of implementing it (4.00). This was followed by the long time required for implementation (3.33) and management doubts about its benefits (3.00). Staff not cooperating (2.33) and difficulties setting up changes in cost monitoring were considered by the responding agricultural holdings to be less compelling reasons for the implementation of $\mathrm{ABC}$ to have failed.

\section{Assessment of the hypotheses}

Hypothesis 1: Most agricultural holdings in the V4 are currently using "conventional" methods to calculate costs.

The hypothesis aims to verify whether the percentage of agricultural holdings using conventional calculation methods is greater than 50\%. Therefore, it was verified using the significance test for a proportion. The variable is the calculation method the agricultural holding uses to estimate costs, determined through the second reply to the questionnaire.

Null hypothesis: The proportion of agricultural holdings in the V4 countries using "conventional" methods to estimate costs is equal to 0.5.

Alternative hypothesis: The proportion of agricultural holdings in the V4 countries using "conventional" methods to estimate costs is greater than 0.5 .

\begin{tabular}{|l|c|c|c|}
\hline $\mathrm{N}$ & Event & Sample $\mathrm{p}$ & $95 \%$ Lower Bound for $\mathrm{p}$ \\
\hline 98 & 59 & 0.602 & 0.514 \\
\hline
\end{tabular}

Source: own processing

Table 10 Assessment of the hypothesis 1.

\section{Test}

Null hypothesis $\mathrm{H}_{0}: \mathrm{p}=0.5$

Alternative hypothesis $\mathrm{H}_{1}: \mathrm{p}>0.5$ $\frac{\text { P-Value }}{0.027}$

Results indicate use of "conventional" calculation methods by $60.2 \%$ of the respondents in the V4, where the p-value of the test is calculated as 0.027 , less than the significance level of 0.05 . Therefore, the null hypothesis is rejected and the validity of the alternative hypothesis is accepted. Because the proportion is greater than 0.5, Hypothesis 1 is confirmed.

Hypothesis 2: The most common reason for agricultural holdings in the V4 not using $\mathrm{ABC}$ is low awareness of the method among managers.

The hypothesis aims to compare the intensity of the reason for not using the $\mathrm{ABC}$ method to estimate costs. This is ascertained from replies to Item 8 from the questionnaire. Therefore, the Wilcoxon signed-rank test was used to verify the intensity of ignorance as the reason for not using $\mathrm{ABC}$ for cost estimates paired with the second most common reason.

Null hypothesis: The difference between not using the ABC test because of ignorance and due to other reasons is zero.

Alternative hypothesis: The difference between not using the ABC test because of ignorance and due to other reasons is greater than zero.

\begin{tabular}{|l|c|c|}
\hline Sample & N & Median \\
\hline comparison of reasons for not using ABC & 31 & 0 \\
\hline
\end{tabular}

Source: own processing

Table 11: Assessment of the hypothesis 2. 


\begin{tabular}{|c|c|c|c|}
\hline Null hypothesis & $\mathrm{H}_{0}$ : & $=0$ & \\
\hline Alternative hypothes & is $\mathrm{H}_{1}$ : & $>0$ & \\
\hline Sample & $\begin{array}{c}\mathrm{N} \\
\text { for Test }\end{array}$ & $\begin{array}{l}\text { Wilcoxon } \\
\text { Statistic }\end{array}$ & P-Value \\
\hline $\begin{array}{l}\text { comparison of reasons } \\
\text { for not using } \mathrm{ABC}\end{array}$ & 8 & 36 & 0.007 \\
\hline
\end{tabular}

Eight responding agricultural holdings replied that the most common reason for not using the $\mathrm{ABC}$ method was because they did not know about it. The other 23 respondents claimed ignorance to be the reason as often as management's doubts about the benefits from using this method. The p-value of the test is 0.007 . This value again lies below the level of significance so the null hypothesis is once more rejected and the validity of the alternative hypothesis is accepted. Hypothesis 2 is confirmed.

Hypothesis 3: There are differences among the countries in the various types of calculation methods used.

Hypothesis 3 aims to verify the correlation between two nominal variables - country and calculation method used to estimate costs. The Chi-square test of independence is therefore used to verify it.

Null hypothesis: The various type of calculation methods used is not dependent on the country where the agriculture holding is located.

Alternative hypothesis: The various type of calculation methods used is dependent on the country where the agriculture holding is located.

Because variable costs and combined outputs are not very often calculated, these groups were merged prior to the calculation for the test. (Table 12).

\section{Chi-Square Test}

\begin{tabular}{cccc} 
& Chi-Square & DF & P-Value \\
\hline Pearson & 5.991 & 6 & 0.424
\end{tabular}

The first table indicates the absolute and relative frequencies for the calculation of variable costs and combined outputs to vary for each country. These are $12.5 \%$ for the Czech Republic, $9.52 \%$ for Hungary and $20 \%$ for Slovakia, with no calculation in Poland.

Frequencies for calculating the mark-up likewise differ: $50.00 \%$ for the Czech Republic, 52.38\% for Hungary, $65.22 \%$ for Poland and $43.33 \%$ for Slovakia. However, the percentage of $\mathrm{ABC}$ costing is approximately the same: $37.50 \%$ for the Czech Republic, 38.10\% for Hungary, $34.78 \%$ for Poland and $36.67 \%$ for Slovakia. Nonetheless, the calculated p-value for testing of 0.424 is relatively high, meaning the described differences are not statistically significant and rather due either to random influences or a low number of respondents. Because the null hypothesis cannot be rejected, it has to be accepted. Hypothesis 3 is not confirmed.

Hypothesis 4: ABC's assessment as time consuming varies depending on the country where the agricultural holding is located.

Hypothesis 4 presumes a relationship between the nominal and ordinal variables, so the KruskalWallis test was used to verify it. The sorting variable is the agricultural holding respondent's country and the ordinal variable the analysis of the amount of time required from the eighth item in the questionnaire.

Null hypothesis: Median amount of time required to implement $\mathrm{ABC}$ is high and equal in all four countries.

Alternative hypothesis: Median amount of time required to implement $\mathrm{ABC}$ is high and varies depending on the country where the agricultural holding is located.

\begin{tabular}{|l|c|c|c|c|c|}
\hline & $\mathrm{CZ}$ & HU & PL & SK & All \\
\hline Calculation of variable costs & 3 & 2 & 0 & 6 & 11 \\
\hline + Calculation of combined outputs & 12.50 & 9.52 & 0 & 20.00 & 11.22 \\
\hline Mark-up calculation & 12 & 11 & 15 & 13 & 51 \\
\hline & 50.00 & 52.38 & 65.22 & 43.33 & 52.04 \\
\hline Process calculation ABC & 9 & 8 & 8 & 11 & 36 \\
\hline & 37.50 & 38.10 & 34.78 & 36.67 & 36.73 \\
\hline All & 24 & 21 & 23 & 30 & 98 \\
\hline
\end{tabular}

Note: Rows -Calculation methods; Columns - Country Source: own research

Table 12: Assessment of the hypothesis 3. 


\begin{tabular}{|l|c|c|c|c|}
\hline Country & $\mathrm{N}$ & Median & Mean Rank & Z-Value \\
\hline $\mathrm{CZ}$ & 7 & 3 & 5.0 & -3.64 \\
\hline $\mathrm{HU}$ & 7 & 4 & 20.5 & 1.49 \\
\hline $\mathrm{PL}$ & 9 & 4 & 17.1 & 0.41 \\
\hline SK & 8 & 4 & 20.5 & 1.63 \\
\hline Overall & 31 & & 16.0 & \\
\hline
\end{tabular}

Source: own research

Table 13: Assessment of the hypothesis 4.

\section{Test}

Null hypothesis

$\mathrm{H}_{0}$ : All medians are equal

Alternative hypothesis $\mathrm{H}_{1}$ : At least one median is different

\begin{tabular}{lccc} 
Method & DF & H-Value & P-Value \\
\hline Adjusted for ties & 3 & 22.69 & 0.000
\end{tabular}

The table makes clear that the medians (4) are the same in three of the four countries. It only varies (3) in the group of respondents from the Czech Republic. The p-value of the test equals nil, so the null hypothesis is rejected and the validity of the alternative hypothesis is accepted. The assessment by different agriculturists of the time consumed to implement $\mathrm{ABC}$ significantly varies in the Czech Republic from the remaining countries (z-value $=-3.64$ ), so Hypothesis $\mathbf{4}$ is confirmed.

Hypothesis 5: Management's doubts about ABC's benefits vary depending on the country where the agricultural holding is located.

The fifth hypothesis was verified in the same way as the fourth hypothesis. The level of doubt among managers ascertained in the eighth question was compared across the four countries.

Null hypothesis: Median level of management doubts about the benefits of $A B C$ is the same across the four countries.

Alternative hypothesis: Median level of management doubts about ABC's benefits varies depending on the country where the agricultural holding is located.

\begin{tabular}{|l|c|c|c|c|}
\hline Country & $\mathrm{N}$ & Median & Mean Rank & Z-Value \\
\hline $\mathrm{CZ}$ & 7 & 3 & 4.5 & -3.80 \\
\hline $\mathrm{HU}$ & 7 & 4 & 20.0 & 1.32 \\
\hline $\mathrm{PL}$ & 9 & 4 & 20.0 & 1.57 \\
\hline SK & 8 & 4 & 18.1 & 0.74 \\
\hline Overall & 31 & & 16.0 & \\
\hline
\end{tabular}

Source: own research

Table 14: Assessment of the hypothesis 5.
Test

Null hypothesis $\quad \mathrm{H}_{0}$ : All medians are equal

Alternative hypothesis $\mathrm{H}_{1}$ : At least one median is different

\begin{tabular}{lccc} 
Method & DF & H-Value & P-Value \\
\hline Adjusted for ties & 3 & 25.58 & 0.000
\end{tabular}

The results were very similar to those from the preceding hypothesis. Here the median was also the same in three of the four countries (4) and only among the group of respondents from the Czech Republic did it vary (3). The test's p-value equals nil so again the alternative hypothesis applies. Significantly less doubt was expressed by agriculturalists in the Czech Republic ( $\mathrm{z}$-value $=-3.80$ ), so Hypothesis 5 is confirmed.

\section{Conclusion}

The analysis revealed the mark-up method to be the most commonly used in agriculture for estimating costs, which was used in 52\% of the agricultural holdings analysed, most commonly in Poland (65\%). It is quite surprising to find almost $94 \%$ of the companies satisfied with this method and not intending to switch away from it.

The analysis also showed low awareness of $\mathrm{ABC}$, with up to $28 \%$ of agricultural holdings expressing no knowledge about it, while $31 \%$ of the farms acquainted with the method are not using it. Even though the respondents admitted their ignorance of $\mathrm{ABC}$, they also assessed it as unsuitable for their agricultural holdings. $3 \%$ of the holdings had tried $\mathrm{ABC}$, but it proved unsuccessful for them.

Agricultural holdings that had implemented ABC and were using it appreciated the more accurate identification of costs, especially of overheads. This advantage achieved the highest possible score among all the V4 countries, except for the Czech Republic. Managers also highly appreciated the accuracy of price estimates, especially in the Czech Republic and Slovakia. Respondents to a questionnaire cited more effective cost management, especially the recognition of the fair value of activities and true cost, as ABC's third biggest advantage. This factor was assessed quite highly especially among respondents from Slovakia and also significantly in the remaining V4 countries. Ranked fourth among the benefits, from their replies to the questionnaires, was ABC's ability to clarify the economic efficiency of activities. Managers in the Czech Republic 
mainly cited this factor. The quality and efficiency of final monthly calculations received the maximum possible score from the Czech respondents. Nevertheless, agricultural holdings in the other V4 countries likewise considered the benefit to be very important. Respondents considered product and customer portfolio optimisation to be the least significant advantage of ABC.

The most common reason for agricultural holdings not using $\mathrm{ABC}$ to estimate costs was unawareness of the method, but another major reason was that their managements doubted the benefit. Respondents in Hungary and Poland were especially convinced thereof, while a majority of respondents in Slovakia and the Czech Republic accordingly agreed. Another important factor in not using $A B C$ is the large amount of time envisaged to be consumed in implementing it. Respondents in Hungary and Poland particularly cited this factor. Resistance to change from staff employed at the agricultural holdings was not considered a significant reason for the failure to introduce ABC. Even though the respondents admitted their ignorance of $\mathrm{ABC}$, they also evaluated it as unsuitable for their agricultural holdings.

The significance test for a proportion confirmed the first hypothesis that most agricultural holdings in the V4 are currently using "conventional" methods to calculate costs. The test results indicated $60.2 \%$ of V4 country respondents using "conventional" calculation methods, while the Wilcoxon signedrank test confirmed the second hypothesis that the most common reason for V4 agricultural holdings not to use $\mathrm{ABC}$ was low awareness among managers of the method. The third hypothesis presumed that there were differences among the countries in the various types of calculation methods used to estimate costs. But the Chi-square test of independence did not confirm this hypothesis. The percentage of agricultural holdings that used activity-based costing for estimation was about the same, in the range of $34-38 \%$, in all four countries. Time consumed to implement ABC was found to vary depending on the country where the agricultural holding is located. The KrusalWallis test found the assessment by agriculturists in the Czech Republic of the time required for $\mathrm{ABC}$ to significantly vary from those in the remaining V4 countries. When ascertaining management doubts about the benefits of $\mathrm{ABC}$, it was found that the perspective taken by the agricultural holdings also varied depending on the country where the agricultural holding is located. Significantly less doubt was expressed by agriculturalists in the Czech Republic.

The observed different results in individual countries can be explained mainly by different information and awareness of managers, willingness to change, efforts to improve a certain situation, different levels of competition, or the general trend of using specific methods in a given country.

From the information obtained, managers at agricultural holdings have little information, in most cases, about $\mathrm{ABC}$ as an appropriate alternative to the outdated "conventional" cost estimate methods practised today. Simultaneously, the benefits are visible, especially for agricultural enterprises, for it to become a powerful tool for improving processes as well as products and services. There are benefits for agriculture mainly because $\mathrm{ABC}$ is more suitable than traditional methods for integrating the high overhead costs agricultural holdings undoubtedly have. It is these high overhead costs that should signal to the holding's management the need for changing the methods which have been so far used to estimate costs, for accurate estimates of costs and for fair valuation of activities and true costing. $\mathrm{ABC}$ allows for more efficient cost management and more accurate price calculations. If an agricultural holding is aware of its internal processes and sub-activities, better budgets can be prepared, the economic performance of its departments can be more accurately measured and the holding can become cost effective. These benefits far exceed the limitations ABC undoubtedly has. Managers are also aware of them, but should not be discouraged because the businesses that have implemented $\mathrm{ABC}$ and are using it have evaluated the benefits highly positively, in particular, ABC's more accurate identification of costs, mainly overheads, as well as the advantages of more effective cost management and the accuracy of price estimates.

Corresponding authors

Ing. Lenka Hudáková Stašová, Ph.D.

Department of Finaces, Faculty of Economics, Technical university of Košice

Němcovej 32, 04001 Košice, Slovakia

Phone: +4215560232 86,E-mail:lenka.hudakova.stasova@tuke.sk 


\section{References}

[1] Allain, E. and Laurin, C. (2018) "Explaining implementation difficulties associated with activitybased costing through system uses“, Journal of Applied Accounting Research, Vol. 19, No. 1, pp. 181-198. ISSN 0967-5426. DOI 10.1108/JAAR-11-2014-0120.

[2] Araújo, J. B. C. N., Souza, A. N., Joaquim, M. S. , Mattos, L. M. and Lustosa Jr., I. M. (2020) "Use of the activity-based costing methodology (ABC) in the cost analysis of successional agroforestry systems“, Agroforestry Systems, Vol. 94, pp. 71-80. ISSN 0167-4366. DOI 10.1007/s10457-019-00368-6.

[3] Arora, A. K. and Raju, M. S. S. (2018) "An analysis of activity based costing practices in selected manufacturing units in India“ Indian Journal of Finance, Vol. 12, No. 12, pp. 22-31. ISSN 0973-8711. DOI 10.17010/ijf/2018/v12i12/139889.

[4] Carli, G. and Canavari, M. (2013) "Introducing direct costing and activity based costing in a farm management system: A conceptual model“", Procedia Technology, 8, pp. 397-405. ISSN 2212-0173. DOI 10.1016/j.protcy.2013.11.052.

[5] Cooper, R. and Kaplan, R. S. (1988) "Measure costs right: make the right decisions“, Harvard Business Review, Vol. 66, No. 5, pp. 96-103. ISSN 0017-8012.

[6] Dalci, I., Tanis, V. and Kosan, L. (2010) "Customer profitability analysis with time-driven activitybased costing: A case study in a hotel“", International Journal of Contemporary Hospitality Management, Vol. 22, No. 5, pp. 609-637. ISSN 0959-6119. DOI 10.1108/09596111011053774.

[7] Dejnega, O. (2011) "Method time driven activity based costing-literature review“, Journal of Applied Economic Sciences, Vol. 6, No. 1, pp. 7-15. ISSN 2393-5162.

[8] Del-Río Sánchez, R., Cornejo, V. R., Valderrama, T. G. and Ortiz, J. S. (2019) "Design of the activities map with the $\mathrm{ABC}$ cost model for the university departments. (Diseño del mapa de actividades por el modelo de costes ABC para los departamentos universitarios)“, Cuadernos de Gestion, Vol.19, No. 2, pp. 159-184. E-ISSN 1988-2157, ISSN 1131-6837. DOI 10.5295/cdg.170824vr.

[9] Dierks, P. and Cokins, G. (2000) "The CAM-I Glossary of Activity-based Management", CAM-I. [Online]. Available: https://www.researchgate.net/publication/295956306_The_CAM-I_glossary_ of_activity-based_management_version_30[Accessed: 04 Jun 2020].

[10] Elhamma, A. (2015) "The relationship between activity based costing, perceived environmental uncertainty and global performance“, International Journal of Management, Accounting and Economics, Vol. 2, No. 1, pp. 73-90. ISSN 2383-2126.

[11] Fei, Z. Y. and Isa, C. R. (2011) "The effect of Activity-Based Costing on firms performance, a study among Chinese manufacturing firms", Australian Journal of Basic and Applied Sciences", Vol. 5, No. 9, pp. 227-237. ISSN 1991-8178.

[12] Gazzarin, C. and Lips, M. (2018) "Joint-cost allocation in farm-activity cost accounting - a methodological overview and new approaches (Gemeinkostenzuteilung in der landwirtschaftlichen betriebszweigabrechnung - eine methodische übersicht und neue ansätze)“, Journal of the Austrian Society of Agricultural Economics, Vol. 27, pp. 10-15. ISSN 18151027.

[13] Gholami, H., Jiran, N. S., Mahmood, S., Saman, M. Z. M., Yusof, N. M., Draskovic, V. and Jovovic, R. (2019) "Application of activity-based costing in estimating the costs of manufacturing process. (Veikla Grindžiamų Išlaidų Taikymas İvertinant Tuščiavidurio Pluošto Membranos Gamybos Išlaidas)“", Transformations in Business and Economics, Vol. 18, No. 2, pp. 839-860. ISSN 16484460.

[14] Johnson, H. T. and Kaplan, R. S. (1987) "Relevance Lost: The Rise and Fall of Management Accounting“, Harvard Business Press, 269 p., ISBN 0875841384.

[15] Kaplan, R. S. and Anderson, S. R. (2004) "Time-driven activity-based costing", Harvard Business Review, Vol. 82, No. 11, pp. 131-138, ISSN 0017-8012. 
[16] Koutouzidou, G., Vazakidis, A., Theodoridis, A. and Batzios, C. (2015) "A review of ABC methodology for agricultural sector", CEUR Workshop Proceedings. $7^{\text {th }}$ International Conference on Information and Communication Technologies in Agriculture, Food and Environment, HAICTA 2015; Kavala; Greece Vol. 1498, pp. 20-25.

[17] Maelah, R. and Ibrahim, D. N. (2007) "Factors Influencing Activity Based Costing (ABC) Adoption in Manufacturing Industry“, Investment Management and Financial Innovations, Vol. 4, No. 2, pp. 113-124. ISSN 1810-4967.

[18] Neto, H. F. M., Agostinho, F., Almeida, C. M. V. B., García, R. R. M. and Giannetti, B. F. (2018) "Activity-based costing using multicriteria drivers: An accounting proposal to boost companies toward sustainability", Frontiers in Energy Research, Vol. 6, No. 36. ISSN 2296598X. DOI 10.3389/fenrg.2018.00036.

[19] Park, Y., Jung, S. and Jahmani, Y. (2019) "Time-Driven Activity-Based Costing Systems for Marketing Decisions“, Studies in Business and Economics, Vol. 14, No. 1, pp. 191-207. ISSN 2344-5416. DOI 10.2478/sbe-2019-0015.

[20] Perevozova, I., Mohnenko, A., Mykhailyshyn, L., Stalinska, O. and Vivchar, O. (2019) "Formation of account of reservoir expenses model", Academy of Accounting and Financial Studies Journal, Vol. 23, No. 2, 6 p. E-ISSN 1528-2635, ISSN 1096-3685.

[21] Sampaio, A. L. M., Akahoshi, W. B. and Lima, E. M. (2011) "Evaluation of the application of the method of activity-based costing (ABC) in agricultural production of grain: Crops temporary", Custos e Agronegocio. Vol. 7, No. 3, pp. 133-160. ISSN 1808-2882.

[22] Schulze, M., Seuring, S. and Ewering, C. (2012) "Applying activity-based costing in a supply chain environment", International Journal of Production Economics.Vol. 135, No. 2, pp. 716-725. ISSN 0925-5273. DOI 10.1016/j.ijpe.2011.10.005.

[23] da Silva, F. F., de Medeiros, V. C., de Lima, D. H. S. and Lucena, E. R. F. C. V. (2019) "Processes and activities cost management: A case study in a cattle breeding company“", Custos e Agronegocio, Vol. 15, No. 2, pp. 87-115. ISSN 1808-2882. 